\title{
Targeted deletion of Traf 2 allows immunosuppression-free islet allograft survival in mice
}

\author{
Jeanette E. Villanueva ${ }^{1,2} \cdot$ Stacey N. Walters $^{1} \cdot$ Mitsuru Saito $^{3} \cdot$ Elisabeth K. Malle $^{1}$. \\ Nathan W. Zammit ${ }^{1}$ - Katherine A. Watson ${ }^{4,5}$ • Robert Brink ${ }^{6}$ • Nicole L. La Gruta ${ }^{4,7}$. \\ Stephen I. Alexander ${ }^{3} \cdot$ Shane T. Grey ${ }^{1}$
}

Received: 27 July 2016 / Accepted: 5 December 2016 / Published online: 6 January 2017

(C) Springer-Verlag Berlin Heidelberg 2017

\begin{abstract}
Aims/hypothesis Administration of anti-CD40 ligand (CD40L) antibodies has been reported to allow long-term islet allograft survival in non-human primates without the need for exogenous immunosuppression. However, the use of anti-CD40 $\mathrm{L}$ antibodies was associated with thromboembolic complications. Targeting downstream intracellular components shared between CD40 and other TNF family co-stimulatory molecules could bypass these complications. TNF receptor associated factor 2 (TRAF2) integrates multiple TNF receptor
\end{abstract}

Electronic supplementary material The online version of this article (doi:10.1007/s00125-016-4198-7) contains peer-reviewed but unedited supplementary material, which is available to authorised users.

Shane T. Grey

s.grey@garvan.org.au

1 Transplantation Immunology Group, Immunology Division, Garvan Institute of Medical Research, 384 Victoria Street,

Darlinghurst, NSW 2010, Australia

2 Present address: Victor Chang Cardiac Research Institute, Darlinghurst, NSW, Australia

3 Centre for Kidney Research, Children's Hospital at Westmead, University of Sydney, Westmead, NSW, Australia

4 Department of Microbiology and Immunology, The Peter Doherty Institute for Infection and Immunity, The University of Melbourne, Parkville, VIC, Australia

5 Present address: Immunology Division, The Walter and Eliza Hall Institute for Medical Research, Melbourne, VIC, Australia

6 B Cell Biology Group, Immunology Division, Garvan Institute of Medical Research, Darlinghurst, NSW, Australia

7 Present address: Department of Biochemistry and Molecular Biology, Infection and Immunity Program, Biomedicine Discovery Institute, Monash University, Clayton, VIC, Australia family signalling pathways that are critical for $\mathrm{T}$ cell activation and may be a central node of alloimmune responses.

Methods T cell-specific Traf2-deficient mice (Traf2TKO) were generated to define the role of TRAF2 in $\mathrm{CD}^{+} \mathrm{T}$ cell effector responses that mediate islet allograft rejection in vivo. In vitro allograft responses were tested using mixed lymphocyte reactions and analysis of IFN- $\gamma$ and granzyme B effector molecule expression. T cell function was assessed using anti-CD3/CD28-mediated proliferation and $\mathrm{T}$ cell polarisation studies.

Results Traf2TKO mice exhibited permanent survival of full MHC-mismatched pancreatic islet allografts without exogenous immunosuppression. Traf2 $\mathrm{TKO} \mathrm{CD}^{+}{ }^{+} \mathrm{T}$ cells exhibited reduced proliferation, activation and acquisition of effector function following T cell receptor stimulation; however, both Traf2TKO $\mathrm{CD}^{+}$and $\mathrm{CD} 8^{+}$T cells exhibited impaired alloantigen-mediated proliferation and acquisition of effector function. In polarisation studies, Traf $2 \mathrm{TKO} \mathrm{CD}^{+} \mathrm{T}$ cells preferentially converted to a $\mathrm{T}$ helper (Th)2 phenotype, but exhibited impaired Th17 differentiation. Without TRAF2, thymocytes exhibited dysregulated TNF-mediated induction of c-Jun N-terminal kinase (JNK) and canonical NFKB pathways. Critically, targeting TRAF2 in T cells did not impair the acute phase of CD8-dependent viral immunity. These data highlight a specific requirement for a TRAF2-NFKB and TRAF2-JNK signalling cascade in $\mathrm{T}$ cell activation and effector function in rejecting islet allografts.

Conclusion/interpretation Targeting TRAF2 may be useful as a therapeutic approach for immunosuppression-free islet allograft survival that avoids the thromboembolic complications associated with the use of anti-CD40L antibodies.

Keywords Allograft - Effector function . Immunosuppression $\cdot$ Islet $\cdot$ T cell $\cdot$ TRAF2 


$\begin{array}{ll}\text { Abbreviations } \\ \text { CFSE } & \text { Carboxyfluorescein diacetate succinimidyl ester } \\ \text { H\&E } & \text { Haematoxylin and eosin } \\ \text { JNK } & \text { c-Jun N-terminal kinase } \\ \text { L } & \text { Ligand } \\ \text { MLR } & \text { Mixed lymphocyte reaction } \\ \text { MST } & \text { Median survival time } \\ \text { siRNA } & \text { Small interfering RNA } \\ \text { Th } & \text { T helper } \\ \text { TNFR } & \text { TNF receptor } \\ \text { TRAF2 } & \text { TNF receptor associated factor 2 } \\ \text { Treg } & \text { T regulatory cell }\end{array}$

\section{Introduction}

Allogeneic islet transplantation is emerging as a promising treatment for type 1 diabetes following the successful outcomes reported by the Collaborative Islet Transplant Registry [1]. A major obstacle to islet transplantation is immune rejection of the transplanted tissue by the recipient's immune system, which can only be overcome with the use of toxic immunosuppression. Greater understanding of the immune response towards transplanted tissues could lead to new therapeutic approaches. TNF receptor (TNFR) family molecules participate in $\mathrm{T}$ cell co-stimulation and provide new therapeutic avenues for transplantation. Blockade of CD27/CD70 and OX40/OX40 ligand (L) interactions, together with CD28 blockade, have been reported to prolong islet allograft survival $[2,3]$. Anti-CD40L antibody administration has been reported to allow long-term islet allograft survival in non-human primates without the need for exogenous immunosuppression [4]. However, the use of a humanised anti-CD40L monoclonal antibody in human clinical trials was halted because of an increased incidence of thromboembolic events [5, 6].

Targeting intracellular $\mathrm{T}$ cell co-stimulation components could bypass the complications that occur when targeting extracellular co-stimulation components. A key intracellular component of TNFR family signalling is TNFR associated factor 2 (TRAF2) [7]. TRAF2 mediates downstream signalling by binding to the cytoplasmic domains of key $\mathrm{T}$ cell surface receptors, including TNFR, CD27, CD30, CD40, GITR, OX40 and 4-1BB [8]. TNFR family members play a critical role in allowing optimal $\mathrm{T}$ cell responses through co-stimulation. Without this $\mathrm{T}$ cell responses are impaired [8], thus providing a mechanistic basis for the efficacy of anti-CD40L antibodies in preclinical islet transplant studies [4]. T cells from dominant negative Traf2 mutant mice have been reported to exhibit reduced proliferation and IFN- $\gamma$ production in response to alloantigens in vitro, but also show impaired $\mathrm{T}$ cell receptor-mediated proliferation, highlighting the therapeutic potential of targeting TRAF2 in preventing $\mathrm{T}$ cell allograft responses $[9,10]$. While promising, these studies did not test whether TRAF2 loss impairs islet allograft rejection in vivo [9]. In this study, we examined whether targeting TRAF2 in T cells would impact islet allograft rejection.

\section{Methods}

Mice Traf $2^{\text {lox/lox }}$ mice were crossed with $L c k$-cre (C57BL/6) mice (Jackson Laboratory, Bar Harbor, ME, USA) [11] to generate $\mathrm{T}$ cell-specific deletion of Traf2 (Traf2TKO). $\mathrm{BALB} / \mathrm{c}, \mathrm{C} 57 \mathrm{BL} / 6$ and $\operatorname{Rag} 1^{-1-}$ mice were from Australian BioResources (Moss Vale, NSW, Australia). Male and female mice were used for the studies. Mice were housed at $22^{\circ} \mathrm{C}$ in a $12 \mathrm{~h}$ light/dark cycle, and were fed ad libitum and received humane care in compliance with guidelines from the Australian National Health and Medical Research Council. The Garvan/St Vincent's Hospital Animal Ethics Committee approved all protocols for animal experiments.

Islet transplantation and histopathology Islets from female BALB/c mice were transplanted to streptozotocin (Sigma-Chemical, St Louis, MO, USA)-induced diabetic floxed, Traf2TKO or Ragl $1^{-1-}$ male recipients as previously described [12]. T regulatory cell (Treg) depletion studies were performed as previously described [13] using $100 \mu \mathrm{g}$ PC61. Graft sections were stained with haematoxylin and eosin (H\&E) or labelled for insulin (1:100; Cell Signaling, Beverly, MA, USA) using the DAKOCytomation EnVision+ System-HRP kit (DAKOCytomation, Glostrup, Denmark), and images were captured using a Leica DM 4000 microscope and DCF450 digital microscope camera using Leica Application Suite software (Leica Microsystems, North Ryde, NSW, Australia).

Western blot Western blots were performed using standard approaches [14]. Antibodies were used at 1:1000 dilution unless otherwise specified: anti-TRAF2 (C-20; Santa Cruz Biotechnology, Dallas, TX, USA); anti-phospho (p)-p38 MAPK (T180/Y182; Cell Signaling Technologies); p38 MAPK (Cell Signaling Technologies); anti-p-c-Jun N-terminal kinase (JNK) (T183/Y185) (Cell Signaling Technologies); SAPK/JNK (Cell Signaling Technologies); anti-IKB $\alpha$ (9242; Cell Signaling Technologies); anti- $\beta$-actin (1:10,000; Sigma-Aldrich, Castle Hill, NSW, Australia); anti-rabbit IgG-horseradish peroxidase (1:5000; GE Healthcare, Rydalmere, NSW, Australia); and anti-mouse IgG-horseradish peroxidase (1:5000; Thermo Scientific, Scoresby, VIC, Australia).

Flow cytometry Lymphocyte subpopulations were analysed using a FACSCanto system (BD Biosciences, San Jose, CA, 
USA) using antibodies and methods as previously described [12]. Data analysis was performed using FlowJo analysis software (TreeStar, Ashland, OR, USA). Light-scatter gating to include live lymphocytes and exclude doublet cells, dead cells and debris was performed unless otherwise specified.

Lymphocyte BrdU incorporation Floxed control and Traf 2 TKO mice (age 6-8 weeks) were given $0.2 \mathrm{ml}$ i.p. BrdU (Sigma-Aldrich; $10 \mathrm{mg} / \mathrm{ml}$ PBS) in five injections at $12 \mathrm{~h}$ intervals. Lymphocytes were harvested $12 \mathrm{~h}$ after the final injection and BrdU incorporation was assessed using the BrdU Flow Kit (BD Biosciences) according to the manufacturer's instructions.

T cell proliferation assays Purified $\mathrm{T}$ cells (Pan T Isolation Kit II; Miltenyi Biotec, Macquarie Park, NSW, Australia) were labelled with carboxyfluorescein diacetate succinimidyl ester (CFSE) ( $0.5 \mu \mathrm{mol} / 1$; Sigma-Aldrich), and $2 \times 10^{5}$ cells/ well were stimulated with immobilised anti-CD3 $(0.1,0.3,1$ and $3 \mu \mathrm{g} / \mathrm{ml}$; BD Biosciences) with or without anti-CD28 ( $5 \mu \mathrm{g} / \mathrm{ml}$; BD Biosciences) for $72 \mathrm{~h}$. For mixed lymphocyte reactions (MLRs), T cells were co-cultured with mitomycin C (Sigma-Aldrich; $25 \mu \mathrm{g} / \mathrm{ml}$ )-treated BALB/c splenocytes in a 1:1 responder to stimulator ratio. $T$ cell proliferation was assessed by flow cytometry based on CFSE dilution.

Treg suppression assay FACS-purified floxed control $\mathrm{CD} 4{ }^{+} \mathrm{CD} 25^{-}$(Teffector) cells were CFSE-labelled and co-cultured with FACS-purified floxed or Traf2TKO $\mathrm{CD} 4{ }^{+} \mathrm{CD} 25^{+}$(Treg) cells at various ratios. Proliferation was calculated as a percentage of suppression vs proliferation of $\mathrm{T}$ cells alone $\left(100 \times\left[1-\% \mathrm{CFSE}^{\text {low }} \mathrm{CD} 4^{+} \mathrm{CD} 25^{-} \mathrm{T}\right.\right.$ cells in co-culture/\% $\mathrm{CFSE}^{\text {low }} \mathrm{CD} 4^{+} \mathrm{CD} 25^{-} \mathrm{T}$ cells alone]).

T cell polarisation assay FACS-sorted floxed or Traf $2 \mathrm{TKO}$ $\mathrm{CD} 4^{+}$-naive $\mathrm{T}$ cells $\left(\mathrm{CD} 3^{+} \mathrm{CD} 4^{+} \mathrm{CD} 25^{-} \mathrm{CD} 62 \mathrm{~L}^{+} \mathrm{CD} 44^{-}\right)$were seeded at $1 \times 10^{5}$ cells/well in a flat-bottom, 96-well plate pre-coated with $1 \mu \mathrm{g} / \mathrm{ml}$ anti-CD3 (BD Biosciences) and co-cultured with $3 \mu \mathrm{g} / \mathrm{ml}$ anti-CD28 or $4 \times 10^{5}$ irradiated (3000 cGy) autologous antigen-presenting cells at $37^{\circ} \mathrm{C}$ with $5 \% \mathrm{CO}_{2}$ for $68 \mathrm{~h}$ under the following conditions: $\mathrm{N}$ (media), $\mathrm{T}$ helper (Th)0 $(5 \mu \mathrm{g} / \mathrm{ml}$ anti-IFN- $\gamma, 5 \mu \mathrm{g} / \mathrm{ml}$ anti-IL-4), Th1 $(5 \mu \mathrm{g} / \mathrm{ml}$ anti-IL-4, $3.5 \mathrm{ng} / \mathrm{ml} \mathrm{IL-12)}$, Th2 $(5 \mu \mathrm{g} / \mathrm{ml}$ anti-IFN- $\gamma, 3.5 \mathrm{ng} / \mathrm{ml}$ IL-4), Th17 $(5 \mu \mathrm{g} / \mathrm{ml}$ anti-IFN- $\gamma$, $5 \mu \mathrm{g} / \mathrm{ml}$ anti-IL-4, $1 \mathrm{ng} / \mathrm{ml}$ TGF- $\beta, 10 \mathrm{ng} / \mathrm{ml} \mathrm{IL-6)} \mathrm{and} \mathrm{Treg}$ $(5 \mu \mathrm{g} / \mathrm{ml}$ anti-IFN- $\gamma, 5 \mu \mathrm{g} / \mathrm{ml}$ anti-IL- $4,1 \mathrm{ng} / \mathrm{ml}$ TGF- $\beta$ ). Cells were treated with phorbol 12-myristate-13-acetate (PMA)/ionomycin and GolgiStop (BD Biosciences) for $4 \mathrm{~h}$ prior to intracellular cytokine labelling.

Inhibition of signalling Purified floxed control $T$ cells were incubated with pyrrolidine dithiocarbamate (NFKB inhibitor; Sigma-Aldrich), SP600125 (JNK inhibitor; Sigma-Aldrich) or
SB203580 (p38 inhibitor; Cell Signaling) for $1 \mathrm{~h}$ at $37^{\circ} \mathrm{C}$ and $5 \% \mathrm{CO}_{2}$, and then stimulated with $3 \mu \mathrm{g} / \mathrm{ml}$ immobilised anti-CD3 for $72 \mathrm{~h}$.

Influenza infection model Floxed and Traf2TKO mice were infected with $1 \times 10^{4}$ plaque-forming units of the $\mathrm{HKx} 31$ (H3N2) strain of the influenza A virus intranasally, and lymphocytes were harvested for staining with phycoerythrin (PE)-conjugated $\mathrm{D}^{\mathrm{b}} \mathrm{NP}_{366}$ or $\mathrm{D}^{\mathrm{b}} \mathrm{PA}_{224}$ tetramers, peptide stimulation and intracellular cytokine staining as previously described [15].

Statistical analysis Kaplan-Meier survival curve analysis using a logrank (Mantel-Cox) test and Dunnett's multiple comparison or unpaired $t$ tests (Mann-Whitney) were performed using GraphPad Prism v6.0b for Macintosh (GraphPad Software, La Jolla, CA, USA). Results were considered statistically significant when $p<0.05$.

\section{Results}

T cell-specific deletion of $\operatorname{Traf} 2$ promotes long-term allograft survival $B A L B / c\left(H-2^{d}\right)$ islets were transplanted under the kidney capsule of streptozotocin-induced diabetic Traf 2 TKO or littermate floxed control (both $\mathrm{H}-2^{\mathrm{b}}$ ) mice. All floxed control recipient mice rejected their islet allograft, with a median survival time (MST) of 20.5 days $(n=4)$. In contrast, approximately $77 \%$ of Traf $2 \mathrm{TKO}$ recipient mice accepted an islet allograft long term (e.g. $>100$ days; $p=0.0012 ; n=13$ ) (Fig. 1a). Graft function was demonstrated by nephrectomy at postoperative day 100 (Fig. 1b). Mononuclear cells were abundant in rejecting grafts from floxed control mice and early (postoperative day <20) islet allografts in Traf2TKO mice (Fig. 1c), whereas long-term surviving islet allografts were characterised by reduced mononuclear cell infiltrate, normal islet morphology and robust insulin production in situ (Fig. 1d). The prolongation of allograft survival in Traf2TKO mice also extended to models of vascularised allografts. Compared with controls, Traf2TKO mice exhibited prolonged skin allograft survival (MST 19 vs 14 days; $p=0.0201$ ) and heterotopic heart allograft survival (MST 9.5 vs 7 days; $p=0.017$; Table 1). Thus, targeted deletion of Traf 2 on T cells allowed long-term islet allograft survival across a full MHC barrier without the need for exogenous immunosuppression.

In another set of experiments, streptozotocin-induced diabetic $\operatorname{Rag} 1^{-1-}$ mice transplanted with $\mathrm{BALB} / \mathrm{c}$ islet allografts received purified $T$ cells from either floxed or Traf2TKO mice 14 days post-transplant. All recipients receiving floxed control $\mathrm{T}$ cells rejected the islet allograft (MST 19 days; $n=4$ ); however, approximately $83 \%$ of mice receiving Traf2TKO T cells exhibited intact and functional islets by histological analysis (MST $>100$ days; $n=6$; 


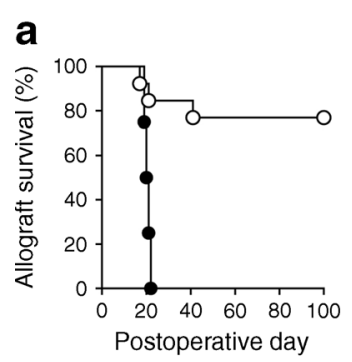

d
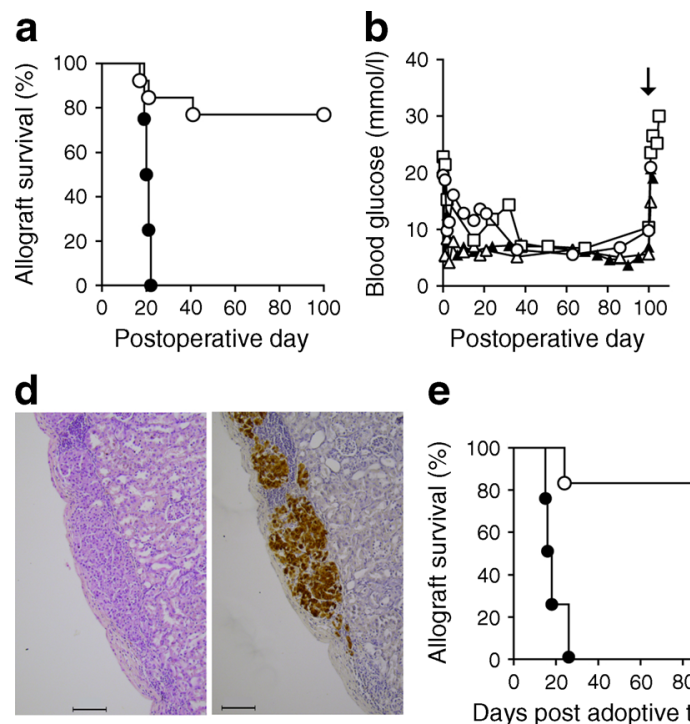

e

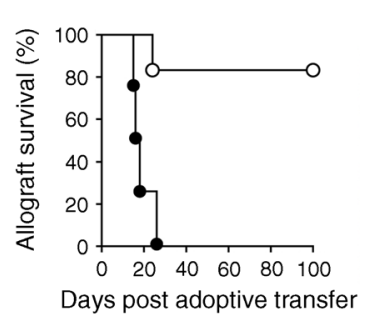

C

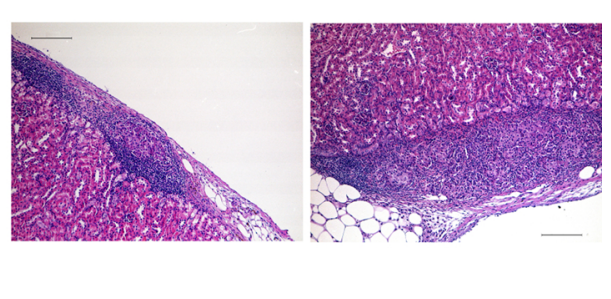

$\mathbf{f}$

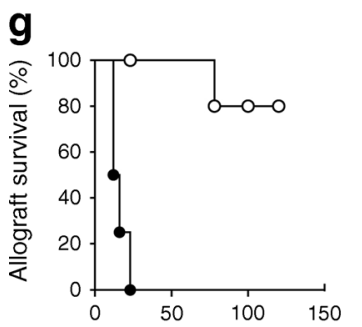

h

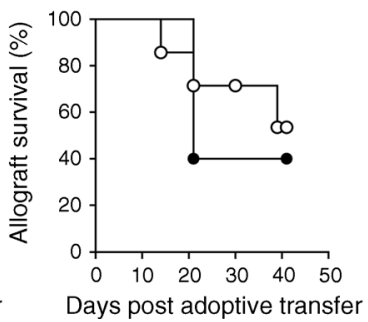
Days post adoptive transfer Days post adoptive transfer

Fig. 1 Long-term islet allograft survival in Traf2TKO mice. (a) Islet allograft survival in floxed control (black circles, $n=4$ ) and Traf2TKO (white circles, $n=13$ ) mice; $p=0.0012$. (b) Blood glucose readings from the Traf 2 TKO cohort $(n=4$; each symbol reflects an individual mouse) followed for 100 days post transplantation and after survival nephrectomy on postoperative day 100 (arrow). (c) H\&E staining of islet allografts in floxed control (left) and Traf2TKO (right) mice $(n=3)$ at postoperative day $<20$; scale bars, $100 \mu \mathrm{m}$. (d) H\&E (left) and insulin labelling (brown; right) of $>100$ day surviving islet allografts in Traf 2 TKO mice; scale bars, $100 \mu \mathrm{m}$. (e) Islet allograft survival in

$p=0.0046$; Fig. 1e, f), indicating that T cell intrinsic TRAF2 is required for islet allograft rejection.

To dissect the role of individual $\mathrm{T}$ cell subsets in islet allograft rejection, purified $\mathrm{CD} 4^{+}$or $\mathrm{CD}^{+} \mathrm{T}$ cells were adoptively transferred to $\operatorname{Rag} 1^{-/-}$transplant recipients. All mice receiving floxed control $\mathrm{CD}^{+} \mathrm{T}$ cells rejected their islet allograft (MST 14 days; $n=4$ ), whereas $80 \%$ of mice transplanted $\mathrm{Rag} \mathrm{I}^{--}$mice receiving $2 \times 10^{6}$ floxed control (black circles; $n=4$ ) or Traf2TKO (white circles; $n=6$ ) T cells; $p=0.0046$. (f) H\&E (left) and insulin labelling (brown; right) of $>100$ day surviving islet allografts in $\mathrm{Ragl}^{-/}$mice receiving Traf2TKO T cells; scale bars, $100 \mu \mathrm{m}$. (g) Islet allograft survival in transplanted $\mathrm{Ragl} \mathrm{I}^{-1-}$ mice receiving $2 \times 10^{6}$ floxed control (black circles; $n=4$ ) or Traf2TKO (white circles; $n=6$ ) $\mathrm{CD}^{+} \mathrm{T}$ cells; $p=0.0011$. (h) Islet allograft survival in transplanted Rag $1^{-1}$ mice receiving $2 \times 10^{6}$ floxed control (black circles; $n=5$ ) or Traf2TKO (white circles; $n=7$ ) $\mathrm{CD}^{+} \mathrm{T}$ cells; $p=0.6536$

receiving Traf $2 \mathrm{TKO} \mathrm{CD}^{+} \mathrm{T}$ cells maintained their islet allograft for $>100$ days $(n=6 ; p=0.0011$; Fig. 1 g). In contrast, adoptive transfer of floxed control or Traf2TKO $\mathrm{CD}^{+} \mathrm{T}$ cells resulted in approximately $50 \%$ islet allograft rejection ( $n=5-7 ; p=0.6884$; Fig. $1 \mathrm{~h})$. These data suggest that $\mathrm{CD} 4^{+} \mathrm{T}$ cells have a specific requirement for TRAF2 to mediate the in vivo islet allograft response.
Table 1 Prolonged survival of vascularised allografts in Traf2TKO mice.

\begin{tabular}{llllll}
\hline Group & Experiment & Allograft rejection days & $\begin{array}{l}\text { MST } \\
\text { (days) }\end{array}$ & $n$ & $p$ value $^{\text {a }}$ \\
\hline 1a & Floxed + BALB/c skin allograft & $10,12,12,12,14,14,14,17$, & 14 & 11 & 0.0201 \\
& & $17,17,17$ & & & \\
1b & Traf2TKO + BALB/c skin allograft & $12,12,14,19,19,19,21,23$ & 19 & 8 & \\
2a & Floxed + BALB/c HHTx & $6,7,7,7,7,9,10$ & 7 & 7 & 0.0170 \\
2b & Traf2TKO + BALB/c HHTx & $7,7,8,8,8,11,11,12,12,14$ & 9.5 & 10 & \\
\hline
\end{tabular}

${ }^{\text {a }}$ Logrank Mantel-Cox test comparing group a vs b

HHTx, heterotopic heart transplant 
Without TRAF2, CD4 ${ }^{+} \mathbf{T}$ cells fail to proliferate after $\mathbf{T}$ cell receptor stimulation Floxed and Traf2TKO total $\mathrm{T}$ cells exhibited comparable proliferation following anti-CD3 alone (Fig. 2a); however, Traf2TKO total T cells showed approximately $20 \%$ reduced proliferation at lower anti-CD3 concentrations $(0.1 \mu \mathrm{g} / \mathrm{ml})$ with anti-CD28 (Fig. 2b). In addition, anti-CD3 stimulated Traf2TKO CD4 ${ }^{+} \mathrm{T}$ cells proliferated less than floxed controls (Fig. 2c). CD28 co-stimulation boosted Traf2TKO $\mathrm{CD}^{+}{ }^{+} \mathrm{T}$ cell proliferation, but it still failed to reach floxed control levels (Fig. 2d). When anti-CD3/CD28-mediated proliferation was compared with anti-CD3 stimulation alone, Traf2TKO $\mathrm{CD}^{+} \mathrm{T}$ cells exhibited a similar proliferation fold-change compared with floxed controls (data not shown), suggesting that TRAF2 loss maintained CD28-mediated responses. In contrast to $\mathrm{CD} 4^{+} \mathrm{T}$ cell proliferation, we have previously shown that Traf2TKO $\mathrm{CD}^{+} \mathrm{T}$ cells showed normal proliferative responses to
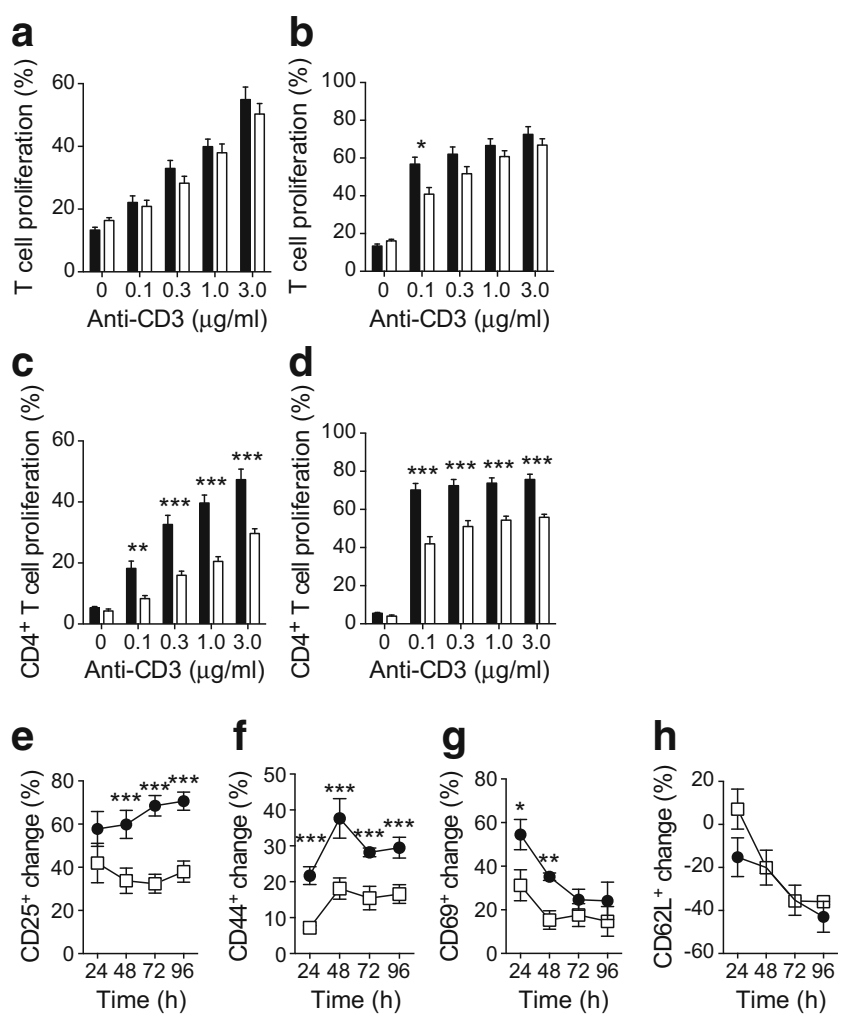

Fig. 2 Reduced anti-CD3-mediated proliferation and activation of Traf2TKO CD $4^{+} \mathrm{T}$ cells. $(\mathbf{a}, \mathbf{b}) \mathrm{T}$ cell proliferation in floxed control (black bars) and Traf $2 \mathrm{TKO}$ (white bars) mice after (a) anti-CD3 stimulation and (b) anti-CD3/CD28 stimulation. Bars represent means \pm SEM. (c, d) $\mathrm{CD}^{+} \mathrm{T}$ cell proliferation in floxed control (black bars) and Traf2TKO (white bars) mice after (c) anti-CD3 stimulation and (d) anti-CD3/CD28 stimulation. Bars represent means \pm SEM. (e-h) Expression of (e) CD25, (f) CD44, (g) CD69 and (h) CD62L in anti-CD3 proliferated floxed control (black circles) and Traf2TKO (white squares) $\mathrm{CD}^{+} \mathrm{T}$ cells analysed at $24 \mathrm{~h}$ intervals by flow cytometry as the percentage change from baseline (unstimulated) expression. Cumulative data from $n=3-5$ mice over three to five independent experiments. Error bars show SEM. $* p<0.05, * * p<0.01, * * * p<0.001$
anti-CD3 and anti-CD3/CD28 [11]. Furthermore, the reduced anti-CD3/CD28-mediated proliferation of Traf2TKO CD4 ${ }^{+} \mathrm{T}$ cells was not due to decreased $\mathrm{CD}^{+} \mathrm{T}$ cell numbers as Traf2TKO and floxed control mice harboured comparable numbers of peripheral $\mathrm{CD}^{+} \mathrm{T}$ cells, as shown in previous studies $[11,16]$. T cell activation marker analysis over a $96 \mathrm{~h}$ period following anti-CD3 stimulation indicated a reduced ability of Traf2TKO CD4 ${ }^{+} \mathrm{T}$ cells to upregulate CD25, CD44 and CD69 as effectively as floxed controls; however, CD62L downregulation was normal (Fig. 2e-h). In contrast to $\mathrm{CD}^{+} \mathrm{T}$ cells, our previous studies demonstrate that activation-induced changes in Traf2TKO $\mathrm{CD}^{+} \mathrm{T}$ cells were equivalent to those of floxed controls [11]. Therefore $\mathrm{CD}^{+} \mathrm{T}$ cells, but not $\mathrm{CD}^{+} \mathrm{T}$ cells, require TRAF2 for optimal activation and proliferation after $\mathrm{T}$ cell receptor engagement in vitro.

TRAF2 is necessary for in vitro $T$ cell effector responses to alloantigen We next measured proliferation and IFN- $\gamma$ and granzyme B expression following co-culture with allogeneic $\mathrm{BALB} / \mathrm{c}$ splenocytes to determine $\mathrm{T}$ cell effector function. Traf2TKO $\mathrm{CD}^{+} \mathrm{T}$ cells exhibited approximately $40 \%$ reduced proliferation to alloantigen compared with floxed $\mathrm{CD}^{+}$T cells (Fig. 3a, b). Furthermore, Traf2TKO CD4 ${ }^{+}$ T cells showed impaired IFN- $\gamma$ (Fig. 3c, d) and granzyme B (Fig. 3e, f) expression relative to floxed control $\mathrm{CD}^{+} \mathrm{T}$ cells. The impaired effector molecule expression was particularly evident in a small proportion of Traf2TKO CD4 ${ }^{+} \mathrm{T}$ cells that underwent extensive proliferation but lacked expression of either IFN- $\gamma$ or granzyme B, an effect that was not observed in the corresponding floxed control MLR. For $\mathrm{CD}^{+} \mathrm{T}$ cells, Traf2TKO $\mathrm{CD}^{+} \mathrm{T}$ cell proliferation was reduced by approximately $50 \%(p<0.0001)$ compared with floxed controls (Fig. 3g, h), with impaired IFN- $\gamma$ (Fig. 3i, j) and granzyme B expression (Fig. 3k, 1) also observed following in vitro alloantigen exposure. Thus, for in vitro alloresponses, TRAF2 is required for full acquisition of $\mathrm{CD}^{+}$and $\mathrm{CD} 8^{+}$ $\mathrm{T}$ cell effector function.

Loss of TRAF2 does not alter $\mathbf{T}$ cell sensitivity to apoptosis To assess whether impaired alloresponses in Traf2TKO mice could be due to reduced peripheral $\mathrm{T}$ cell turnover, floxed control and Traf2TKO mice were treated with the thymidine analogue BrdU. Analysis of BrdU incorporation revealed no discernible differences in $\mathrm{BrdU}^{+} \mathrm{CD} 4^{+}$and $\mathrm{BrdU}^{+} \mathrm{CD}^{+}$ $\mathrm{T}$ cells between floxed control and Traf2TKO mice (see electronic supplementary material [ESM] Fig. 1a, b). Furthermore, no differences were observed in Bcl-2 expression between floxed control and Traf2TKO CD4 ${ }^{+}$mice (ESM Fig. 1c), or in $\mathrm{CD}^{+}$T cells [11] or lymphocyte viability (ESM Fig. 2). These data suggest that the impaired T cell alloresponse seen in Traf2TKO mice is not due to reduced peripheral $\mathrm{T}$ cell turnover or $\mathrm{T}$ cell survival. 
Fig. 3 Impaired Traf 2 TKO $\mathrm{CD}^{+}{ }^{+} \mathrm{T}$ effector responses to alloantigen in an MLR. Proliferation of CFSE-labelled floxed control or Traf2TKO T cells (both $\mathrm{H}-2^{\mathrm{b}}$ ) co-cultured with mitomycin-C-treated BALB/c splenocytes (H-2 ${ }^{\mathrm{d}}$ ) for 3 days. (a) Representative $\mathrm{CD} 4^{+} \mathrm{T}$ cell proliferation FACS plots. Shaded histogram represents unstimulated $\mathrm{T}$ cells. Cumulative data are shown in (b). (c) Representative $\mathrm{CD}^{+}{ }^{+} \mathrm{T}$ cell IFN- $\gamma^{+}$expression FACS plots. (d) Cumulative data from (c) of $\mathrm{CFSE}^{-} \mathrm{IFN}-\gamma^{+} \mathrm{CD}^{+}{ }^{+} \mathrm{T}$ cells. (e) Representative $\mathrm{CD} 4^{+} \mathrm{T}$ cell granzyme $\mathrm{B}$ expression FACS plots. (f) Cumulative data from (e) of CFSE granzyme $\mathrm{B}^{+} \mathrm{CD}^{+} \mathrm{T}$ cells. (g) Representative $\mathrm{CD} 8^{+} \mathrm{T}$ cell proliferation FACS plots. Shaded histogram represents unstimulated $\mathrm{T}$ cells. Cumulative data are shown in (h). (i) Representative $\mathrm{CD}^{+} \mathrm{T}$ cell IFN- $\gamma^{+}$expression FACS plots. (j) Cumulative data from (i) of CFSE IFN- $\gamma^{+} \mathrm{CD}^{+}{ }^{+} \mathrm{T}$ cells. (k) Representative $\mathrm{CD} 8^{+} \mathrm{T}$ cell granzyme B expression FACS plots. (I) Cumulative data from (k) of $\mathrm{CFSE}^{-}$granzyme $\mathrm{B}^{+} \mathrm{CD} 8^{+}$

$T$ cells. Bars represent means \pm SEM; $n=3$ mice over two independent experiments; $* p<0.0001$ a

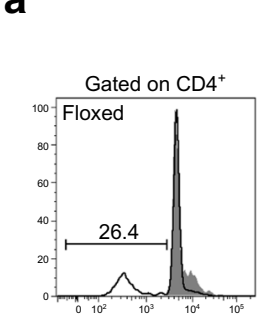

C
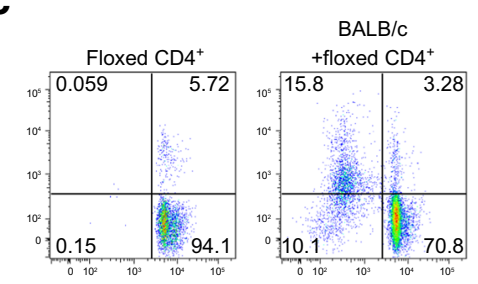

$\mathbf{e}$
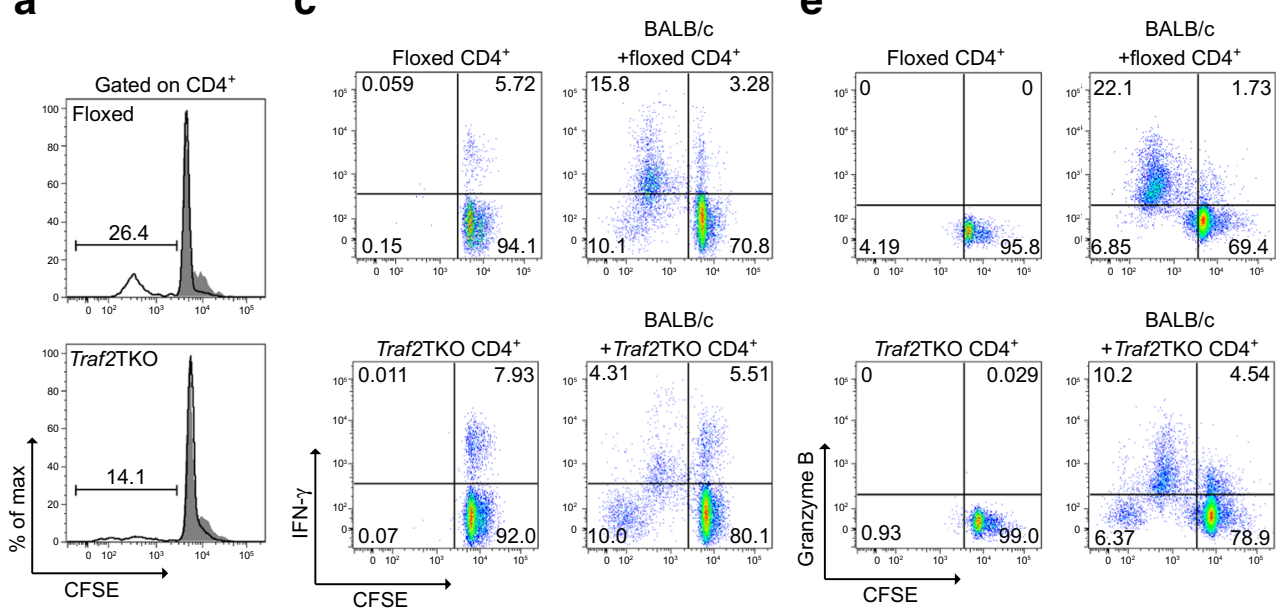

BALB/C
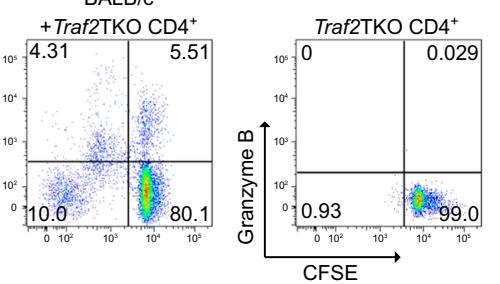

$B A L B / c$
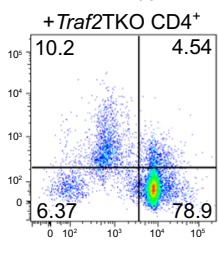

d

f
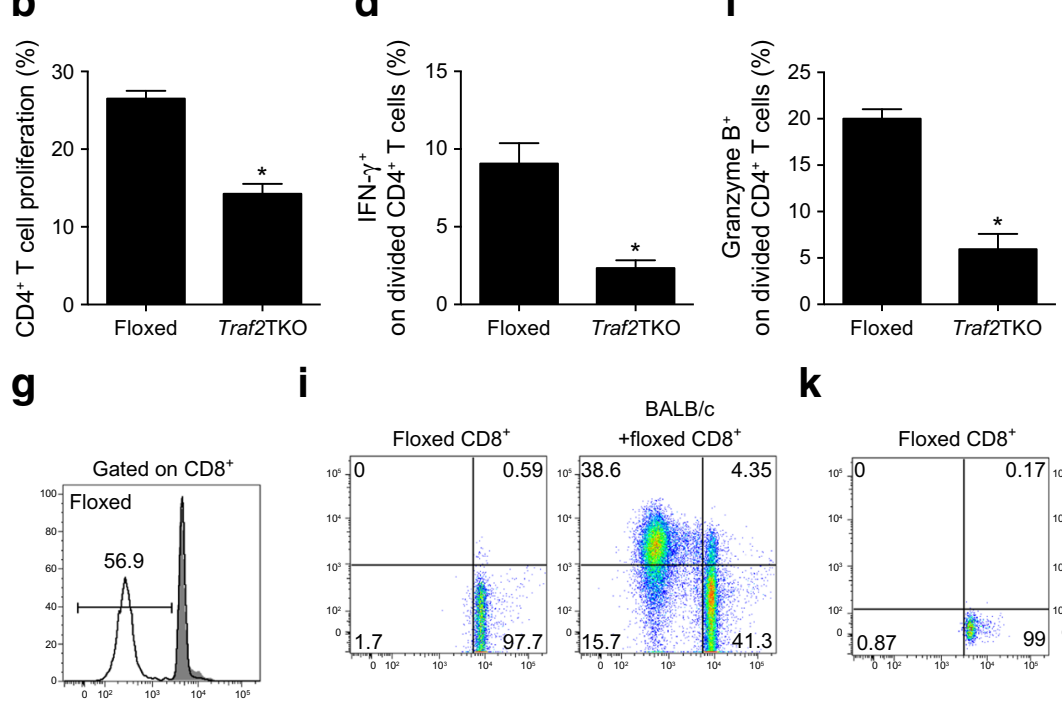

i

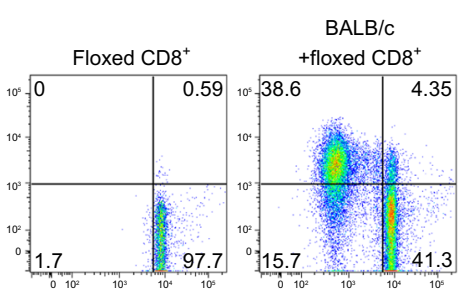

k
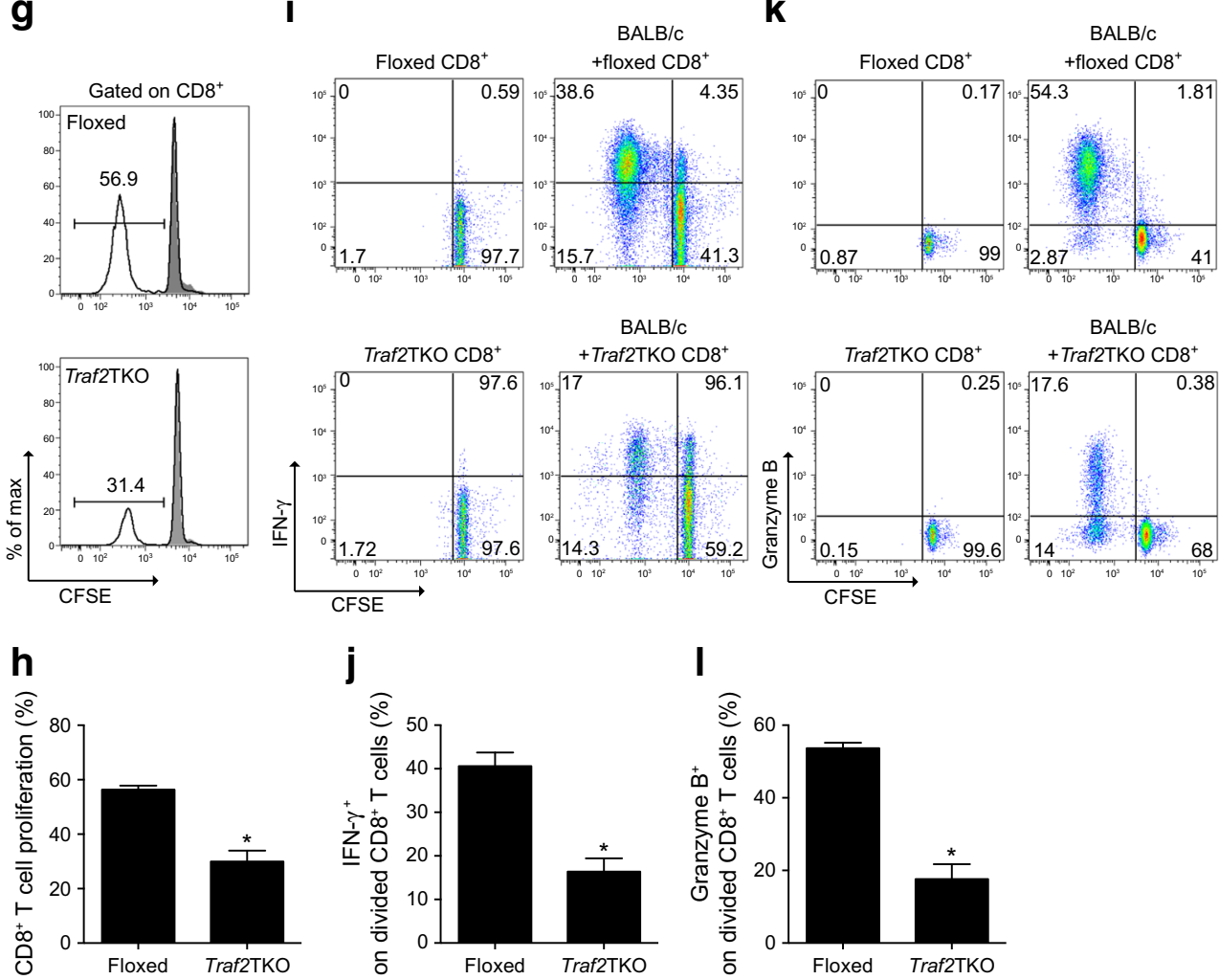

There is a specific requirement for the TRAF2-JNK and TRAF2-NFKB signalling cascades for $T$ cell activation Following receptor ligation of TNFR family members, TRAF2 mediates signalling through the canonical NFKB,
p38/MAPK and JNK pathways [17]. Compared with floxed controls, Traf2TKO thymocytes displayed reduced TNF- $\alpha$-induced p38 phosphorylation, whereas the kinetics of canonical NFKB (IKB $\alpha$ degradation) and JNK 
phosphorylation were significantly delayed (Fig. 4a). Thus, TRAF2 governs the timing of intracellular signalling pathways following TNF- $\alpha$ stimulation.

Pharmacological inhibition of these signalling pathways demonstrated that both JNK and NFKB activation, but not p38, were critical for $\mathrm{CD}^{+} \mathrm{T}$ cell blasting (Fig. 4b), as well as for high expression levels of CD25 and CD44 (Fig. 4c, d). For $\mathrm{CD}^{+} \mathrm{T}$ cells, blasting and high CD44 expression was dependent upon NFKB and JNK signalling but not p38 signalling, whereas CD25 expression was most dependent upon NFKB signalling (Fig. 4e-g). These data suggest a specific requirement for the TRAF2-JNK and TRAF2-NFKB signalling cascades in $\mathrm{T}$ cell activation and islet allograft rejection.

TRAF2 deficiency promotes $\mathrm{Th} 2$ and suppresses $\mathrm{Th} 17 \mathrm{~T}$ cell differentiation Because $\mathrm{CD}^{+} \mathrm{T}$ cells were found to rely upon TRAF2-dependent signals, the ability of Traf2TKO $\mathrm{CD}^{+}{ }^{+} \mathrm{T}$ cells to differentiate into effector subsets was examined. Purified naive $\mathrm{CD}^{+}{ }^{+} \mathrm{T}$ cells from floxed control and Traf $2 \mathrm{TKO}$ mice were cultured under different Th-polarising conditions, and $\mathrm{T}$ cell fate $(\mathrm{N}, \mathrm{Th} 0, \mathrm{Th} 1, \mathrm{Th} 2$, Th17 and Treg) was determined by flow cytometry (Fig. 5). Under Th1 conditions, Traf2TKO and floxed control naive
$\mathrm{CD}^{+} \mathrm{T}$ cells showed comparable frequencies of IFN- $\gamma^{+}$ Th1-type cells (Fig. 5a, c). Under Th2 conditions, Traf2TKO naive $\mathrm{CD}^{+} \mathrm{T}$ cells showed an approximately sevenfold increase in IL-13 ${ }^{+}$Th2-type cells compared with controls (Fig. 5a, d). Under Th17 polarising conditions, Traf2TKO naive $\mathrm{CD}^{+} \mathrm{T}$ cells failed to differentiate into IL-17 ${ }^{+}$Th17-type cells to floxed control levels (Fig. 5b, e); however, under the same Th17 conditions, Traf $2 \mathrm{TKO}$ cells preferentially expressed the Treg marker FOXP3 (Fig. 5b, f). The increased propensity towards $\mathrm{FOXP}^{+}$differentiation was also observed under Treg conditions, although this was not statistically significant (Fig. 5g). The differentiation profile of Traf2TKO cells favouring Th2-type and Treg cells and Th17-type inhibition was also observed following polarisation using anti-CD3 with autologous antigen-presenting cells (data not shown). These data indicate that under specific Th-polarising conditions, loss of TRAF2 strongly skews $\mathrm{CD}^{+}{ }^{+}$T cells towards Th2 differentiation, but strongly inhibits Th17 cell differentiation.

Islet allograft survival in Traf2TKO mice is Treg independent Traf2TKO mice showed increased frequencies of naturally occurring Tregs $\left(\mathrm{CD} 4^{+} \mathrm{CD} 25^{+} \mathrm{FOXP} 3^{+}\right)$ compared with floxed control mice (Fig. 6a, b) but normal
Fig. 4 Specific requirement for TRAF2-JNK and TRAF2-NFKB signalling cascades for $\mathrm{T}$ cell activation. (a) Western blot analysis of TRAF2, p-p38, p38, $\mathrm{I} \kappa \mathrm{B} \alpha, \mathrm{pJNK}, \mathrm{JNK}$ and $\beta$-actin in floxed control and Traf2TKO thymocytes following $200 \mathrm{U}$ TNF- $\alpha$ stimulation. Data are representative of three independent experiments. (b-g) Purified floxed control T cells pretreated with pyrrolidine dithiocarbamate $(\mathrm{NF} \kappa \mathrm{B}$ inhibitor [i]), SB203580 (p38i), SP600125 (JNKi) or vehicle control (DMSO) and anti-CD3-mediated lymphocyte blasting and activation assessed by flow cytometry after $72 \mathrm{~h}$. (b) $\mathrm{CD}^{+} \mathrm{T}$ cell blasting; (c) $\mathrm{CD} 4^{+} \mathrm{CD} 25^{+} \mathrm{T}$ cell percentage; (d) $\mathrm{CD} 4^{+} \mathrm{CD} 44^{+}$ $\mathrm{T}$ cell percentage; (e) $\mathrm{CD}^{+} \mathrm{T}$ cell blasting; (f) $\mathrm{CD}^{+} \mathrm{CD} 25^{+} \mathrm{T}$ cell percentage; (g) $\mathrm{CD} 8^{+} \mathrm{CD} 44^{+} \mathrm{T}$ cell percentage; $n=3$ mice. Bars represent means \pm SEM. $* * * p<0.001$

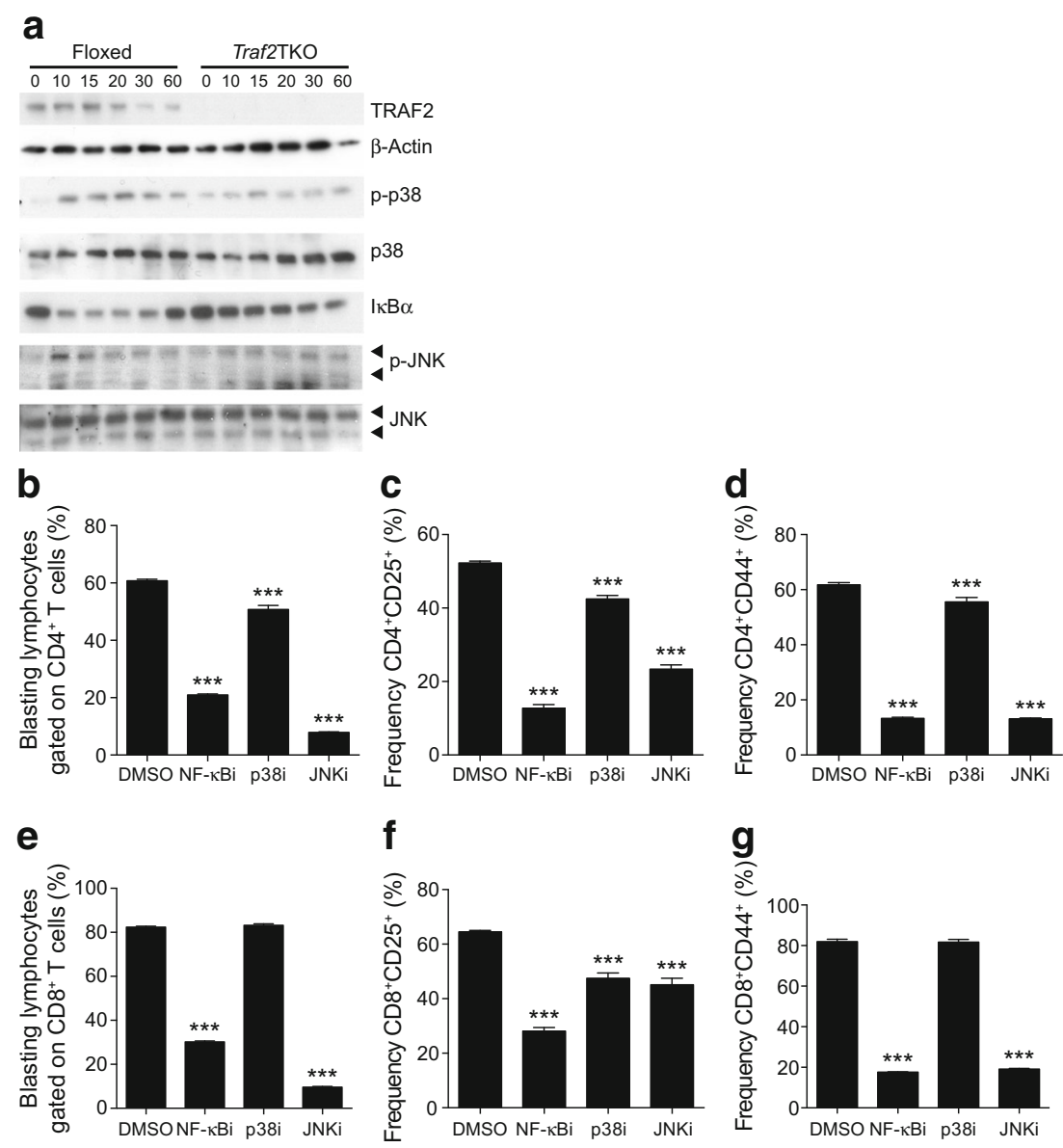


Fig. 5 Loss of TRAF2 strongly enhances Th2 and inhibits Th17 T cell differentiation. FACS-sorted naive $\mathrm{CD}^{+} \mathrm{T}$ cells

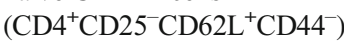
were cultured with anti-CD3/ CD28 for $72 \mathrm{~h}$ under N, Th0, Th1, Th2, Th17 and Treg polarising conditions. (a, b) Representative FACS plots of (a) Th1 and Th2 and (b) Th17 and Treg polarisation. (c, d) Cumulative data of (c) IFN- $\gamma^{+}$and (d) IL$13^{+} \mathrm{CD} 4^{+} \mathrm{T}$ cells in Th1 and Th2 conditions. (e-g) Cumulative data of (e) IL- $17^{+}$and (f)

$\mathrm{FOXP}^{+} \mathrm{CD}^{+} \mathrm{T}$ cells in Th17 conditions and (g) $\mathrm{FOXP}^{+} \mathrm{CD}^{+}$ $\mathrm{T}$ cells Treg conditions. Data are from $n=3-4$ mice pooled over two independent experiments shown as means \pm SEM. $* * p<0.01, * * * p<0.001$

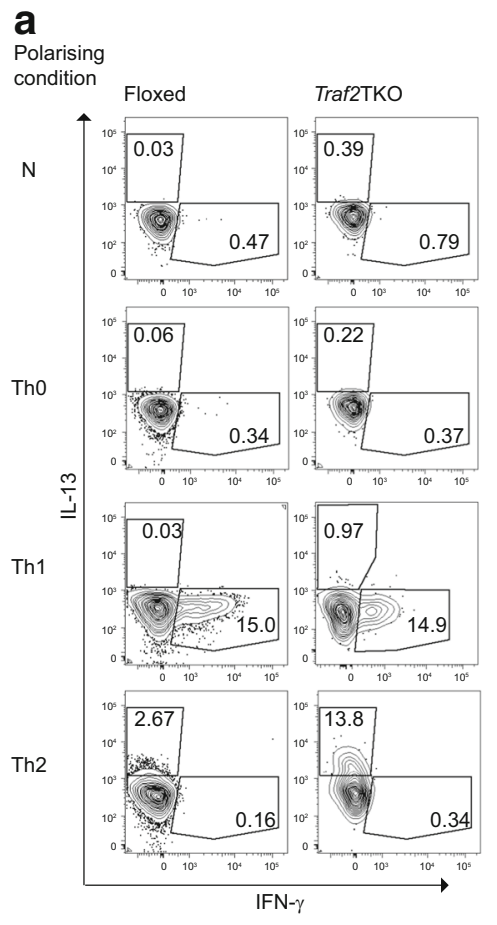

b

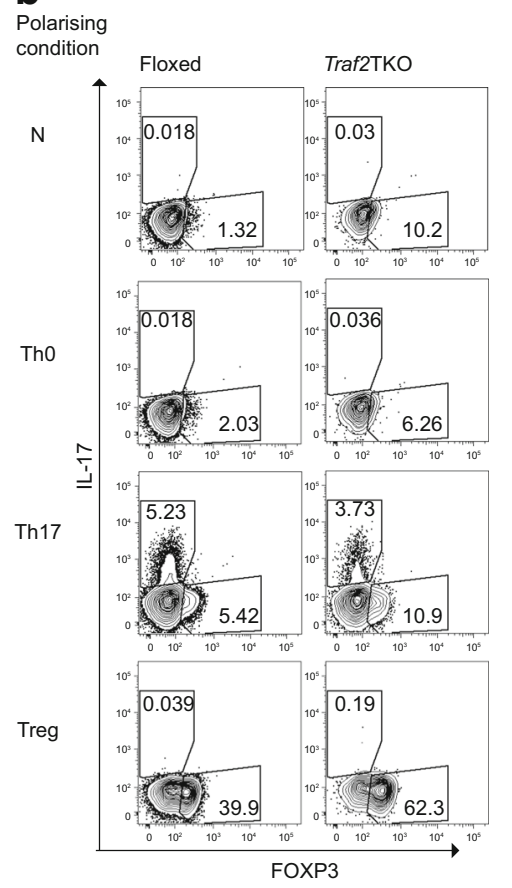

C
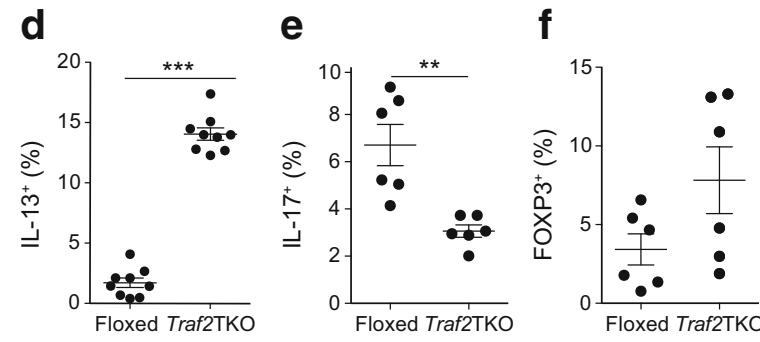

(9)
Treg absolute numbers (Fig. 6c) and normal levels of well-characterised Treg-associated activation markers, with the exception of reduced CD44 expression (Fig. 6d) suggestive of Treg suppressive activity [18]. However, Traf2TKO Tregs exhibited normal in vitro T cell suppression (Fig. 6e). Furthermore, in vivo Treg depletion with the anti-CD25 monoclonal antibody PC61 (Fig. 6f) did not impact islet allograft survival in Traf2TKO mice (Fig. 6g). These data indicate that islet allograft acceptance in Traf2TKO mice is Treg independent and suggest impaired $\mathrm{T}$ cell effector function. Indeed, in an MLR, purified Traf2TKO effector $\left(\mathrm{CD} 4^{+} \mathrm{CD} 25^{-}\right) \mathrm{T}$ cells showed markedly reduced proliferation (Fig. 6h) and activation (CD44 expression) (Fig. 6i, j) compared with their floxed control counterparts, supporting this conclusion.

Maintenance of protective immunity in Traf2TKO mice Our study shows that functional TRAF2 is necessary for $\mathrm{T}$ cell-mediated islet allograft rejection, and highlights targeting TRAF2 as a possible therapeutic approach. To address the critical question of whether TRAF2 deletion impairs protective immune responses, we used a well-studied model of viral immunity. Following infection with $\mathrm{HK} \times 31$ influenza A (H3N2), both floxed and Traf $2 \mathrm{TKO}$ mice demonstrated similar antigen-specific $\mathrm{CD} 8^{+}$ $\mathrm{T}$ cell responsiveness during the acute phase (day 10) of infection, with no differences observed in splenic and bronchoalveolar lavage $\mathrm{D}^{\mathrm{b}} \mathrm{NP} 366-$ and $\mathrm{N}^{\mathrm{b}} \mathrm{PA} 244$-specific $\mathrm{CD}^{+} \mathrm{T}$ cell numbers (ESM Fig. 3a, b) or viral-specific $\mathrm{CD} 8^{+} \mathrm{IFN}-\gamma^{+}$cell numbers (ESM Fig. $3 \mathrm{c}$, d). Therefore, $\mathrm{CD} 8^{+} \mathrm{T}$ cell-dependent acute influenza-specific responses remained intact following $\mathrm{T}$ cell-specific deletion of Traf2. Thus, targeting TRAF2 allowed islet allograft survival but did not impair the acute antiviral $\mathrm{CD} 8^{+} \mathrm{T}$ cell response.

\section{Discussion}

The impaired islet allograft rejection in Traf2TKO mice was not due to absolute immune anergy, since lymphocyte migration during the early islet allograft response was intact and regulatory $\mathrm{T}$ cell numbers and function were maintained. Loss of TRAF2 impaired in vitro $\mathrm{CD} 4^{+}$and $\mathrm{CD} 8^{+} \mathrm{T}$ cell alloreactivity; however, the requirement for TRAF2 for 
Fig. 6 Prolonged allograft survival in Traf2TKO mice is Treg independent. (a-e) Flow cytometric analysis of floxed and Traf2TKO CD $4^{+} \mathrm{CD} 25^{+} \mathrm{FOXP} 3^{+}$

Treg $(\mathbf{a}, \mathbf{b})$ frequency, $(\mathbf{c})$ cell number and (d) cell surface activation markers. Black solid line, Traf2TKO; grey area, floxed; black dotted line, isotype control; $n=9-11$ mice over three independent experiments. (e) Treg-mediated suppression of floxed (black circles) or Traf2TKO (white circles) $\mathrm{CD} 4^{+} \mathrm{CD} 25^{+} \mathrm{T}$ cells co-cultured with CFSE-labelled floxed $\mathrm{CD} 4^{+} \mathrm{CD} 25^{-} \mathrm{T}$ cells. Error bars show SEM. Statistical analysis using unpaired $t$ test; pooled cells from $n=14-16$ mice over three independent experiments. (f) Peripheral blood $\mathrm{CD} 4{ }^{+} \mathrm{CD} 25^{+} \mathrm{FOXP}^{+}{ }^{+} \mathrm{T}$ cell percentage of floxed (black circles) and Traf2TKO (white circles) mice after $100 \mu \mathrm{g}$ PC61. Error bars show SEM; $n=5$ mice. (g) $\mathrm{BALB} / \mathrm{c}$ islet allograft survival in floxed or C57BL/6 wild-type and Traf2TKO mice treated with PC61 or isotype control 3 days before receiving allografts.

Statistical analysis using logrank (Mantel-Cox) test; black squares, C57BL/6 untreated $(n=4)$; white squares, Traf 2 TKO untreated $(n=3)$; black circles, floxed PC61 treated $(n=6)$; white circles, Traf2TKO PC61 treated $(n=5)$. (h, i) CFSE-labelled floxed or Traf 2 TKO CD4 ${ }^{+} \mathrm{CD} 25^{-} \mathrm{T}$ cells co-cultured with mitomycin-Ctreated BALB/c splenocytes, with (h) proliferation and (i, j) CD44 expression analysed by flow cytometry after 3 days. Line, Traf2TKO; grey area, floxed; $n=5$ mice over three independent experiments; $* * * p<0.001$ a

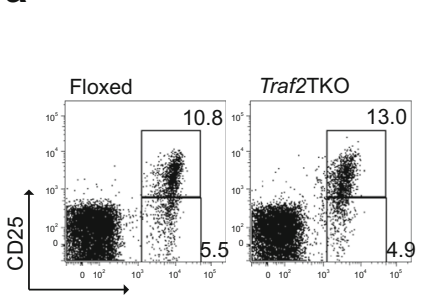

b

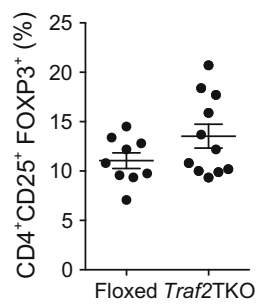

C

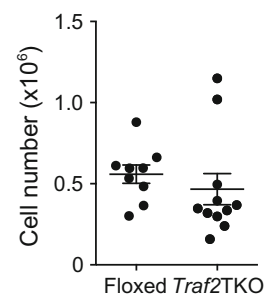

d
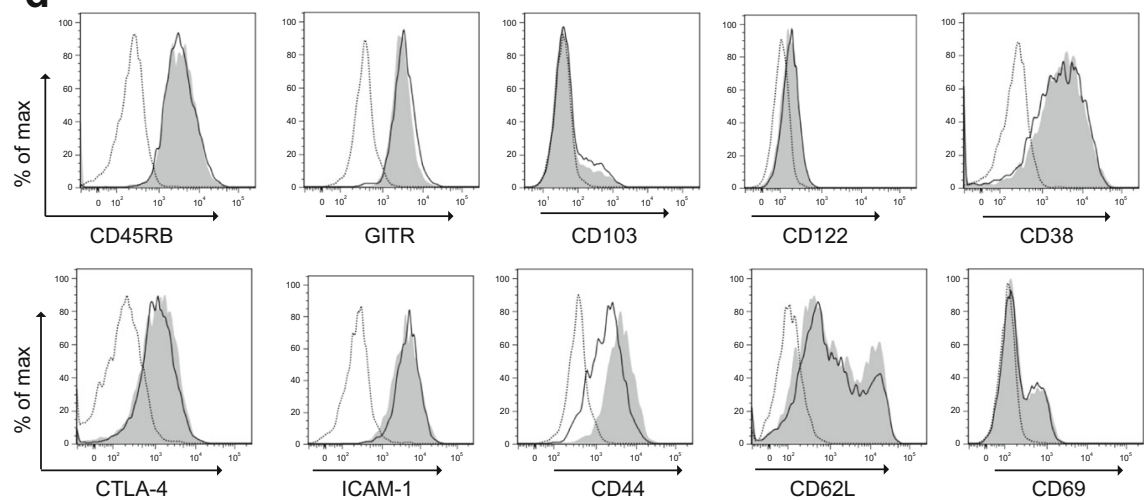

e

f
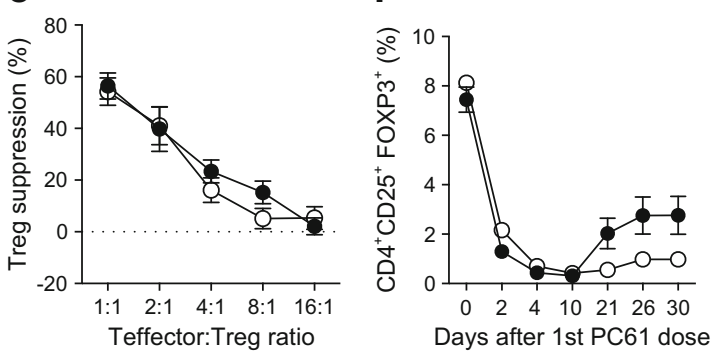

g

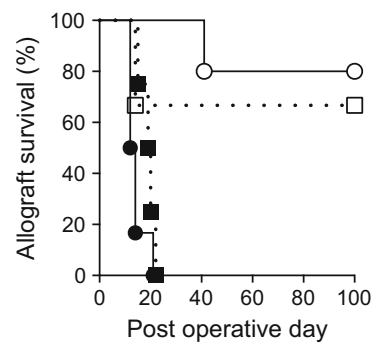

j

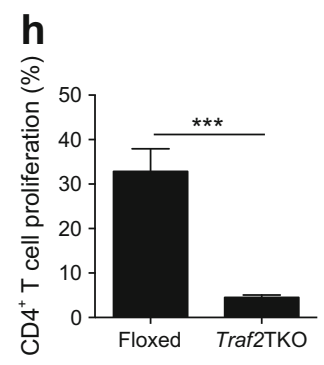

i

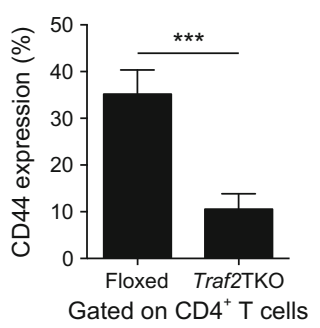

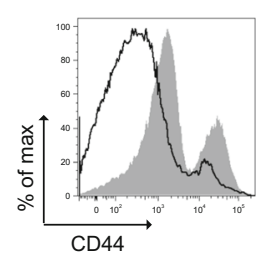

in vivo alloresponses was specific for $\mathrm{CD} 4^{+} \mathrm{T}$ cells. In addition, while loss of TRAF2 limited $\mathrm{CD}^{+}{ }^{+}$anti-CD3-mediated proliferation and $\mathrm{T}$ effector function, Traf $2 \mathrm{TKO} \mathrm{CD} 8^{+} \mathrm{T}$ cells maintained normal $\mathrm{T}$ cell activation and proliferation to CD3/CD28 signals, and were able to mount an effective acute-phase response to viral antigen, a naive $\mathrm{CD} 8^{+} \mathrm{T}$ cell-dependent process [19]. In contrast to Traf $2 \mathrm{TKO} \mathrm{CD} 8^{+} \mathrm{T}$ cells, Traf2TKO $\mathrm{CD}^{+} \mathrm{T}$ cells displayed a reduced activation status (i.e. reduced CD25 and CD44 expression but normal CD62L expression) and decreased CD3/CD28-mediated proliferation. The activation defects of Traf $2 \mathrm{TKO} \mathrm{CD} 4^{+} \mathrm{T}$ cells may reflect the involvement of TRAF2 with TNFR family co-stimulation molecules (i.e. OX40 and 4-1BB) that enhance their expression on T cells after initial activation [20,21].

The dysregulated downstream signalling pathways in the absence of TRAF2 may consequently result in the altered T cell activation status observed in this study. Traf 2 deletion preferentially skewed $\mathrm{T}$ cells towards a Th2-like profile - a possible consequence of aberrant JNK signalling since JNK2-knockout $\mathrm{T}$ cells are highly Th2-like [22]. Th2 
cytokines such as IL-13 and IL-4 are coordinately regulated [23] and are associated with prolonged allograft survival. Impaired cardiac allograft rejection has previously been observed, with long-term surviving cardiac allografts exhibiting high expression of IL-4 [24, 25] and following IL-13 administration in rodents [26], whereas impaired donor-derived IL-13 levels have been correlated with an increased severity of graft-vs-host disease [27]. Furthermore, similar to $\mathrm{CD} 30^{-1-} \mathrm{CD} 4^{+} \mathrm{T}$ cells [28], Traf $2 \mathrm{TKO} \mathrm{CD}^{+}{ }^{\mathrm{T}}$ cells were unable to differentiate into IL- $17^{+}$Th17 cells. Blockade of IL-17 has been shown to prolong cardiac allograft survival $[29,30]$. These studies suggest that Th17 inhibition and an increased Th2 phenotype propensity of Traf $2 \mathrm{TKO} \mathrm{CD}_{4}^{+}$ $\mathrm{T}$ cells could contribute to impaired islet allograft rejection.

Our studies highlight TRAF2 as a potential drug target to improve islet transplant outcomes. While complete ablation of TRAF2 is embryonic-lethal, due to the critical and non-redundant role of TRAF2 in embryogenesis [31], postpartum TRAF2 blockade may not carry these risks. Furthermore, whether transient inhibition of TRAF2 prior to transplantation would promote delayed allograft rejection is also unknown. Future studies could potentially harness the use of small interfering (si)RNA technologies to block TRAF2 specifically on $\mathrm{T}$ cells, similar to the $\mathrm{T}$ cell-specific siRNA treatment that is used to reduce HIV infection [32]. The natural biology of TRAF2 may also offer up potential therapeutic opportunities. New drugs targeting ubiquitin-editing enzymes such as lenalidomide, which targets the E3 ubiquitin ligase cereblon, are in clinical trials [33]. Furthermore, simultaneous targeting of canonical NFKB and JNK signalling may replicate TRAF2 blockade and offer an alternative therapeutic avenue $[34,35]$. The information gathered here about the processes in which TRAF2 is critical for T cell-mediated islet allograft destruction can be used to identify targets for immune modulation that could be applied in the clinical setting of islet transplantation.

Acknowledgements We thank K. Webster, R. Salomon and R. Wirasinha (Immunology Division, Garvan Institute, Darlinghurst, NSW, Australia) for insightful discussion and technical assistance; D. Saunders (School of Medical Sciences, UNSW, Sydney, NSW, Australia) for insightful discussion; and J. Fisher (Australian BioResources, Moss Vale, NSW, Australia) for technical assistance.

Data availability All data generated or analysed during this study are included in this published article (and its supplementary information files).

Funding This work was supported in part by a philanthropic grant from the Ross Trust and grants from the National Health and Medical Research Council (NHMRC) (427695) and Australian Research Council (ARC; 201302657) awarded to STG. JEV and NWZ were each supported by an Australian Postgraduate Award. NLL is a Sylvia and Charles Viertel Senior Medical Research Fellow and is supported by funding from the
NHMRC (1071916). STG is an ARC Future Fellow and an NHMRC Research Fellow (569825). The authors have no conflicting financial interests.

Duality of interest The authors declare that there is no duality of interest associated with this manuscript.

Author contributions JEV and SNW conducted and analysed islet and skin transplant and histological studies. MS and SIA conducted and analysed heart transplant studies. JEV conducted and analysed in vitro T cells assays, cell signalling studies and T cell polarisation studies. NWZ and EKM established and analysed inhibitor and signalling studies. KAW and NLL designed, conducted, analysed and interpreted viral immunity experiments. RB generated critical genetic tools for the study. JEV and STG interpreted all findings and co-wrote the manuscript. All authors were involved in revising the article critically for important intellectual content and gave final approval of the version to be published. STG designed and led the study and, as guarantor, takes responsibility for the contents of the article.

\section{References}

1. Barton FB, Rickels MR, Alejandro R et al (2012) Improvement in outcomes of clinical islet transplantation: 1999-2010. Diabetes Care 35:1436-1445

2. Wu T, Hering B, Kirchof N, Sutherland D, Yagita H, Guo Z (2001) The effect of OX40/OX40L and CD27/CD70 pathways on allogeneic islet graft rejection. Transplant Proc 33:217-218

3. Wang GM, Yang Y, Jin YZ et al (2005) Blockade of both CD28/B7 and OX40/OX40L co-stimulatory signal pathways prolongs the survival of islet xenografts. Transplant Proc 37:4449-4451

4. Kenyon NS, Chatzipetrou M, Masetti M et al (1999) Long-term survival and function of intrahepatic islet allografts in rhesus monkeys treated with humanized anti-CD154. Proc Natl Acad Sci U S A 96:8132-8137

5. Boumpas DT, Furie R, Manzi S et al (2003) A short course of BG9588 (anti-CD40 ligand antibody) improves serologic activity and decreases hematuria in patients with proliferative lupus glomerulonephritis. Arthritis Rheum 48:719-727

6. Henn V, Slupsky JR, Grafe M et al (1998) CD40 ligand on activated platelets triggers an inflammatory reaction of endothelial cells. Nature 391:591-594

7. Xie P (2013) TRAF molecules in cell signaling and in human diseases. J Mol Signal 8:7

8. Croft M (2003) Co-stimulatory members of the TNFR family: keys to effective T cell immunity? Nat Rev Immunol 3:609-620

9. Cannons JL, Bertram EM, Watts TH (2002) Cutting edge: profound defect in T cell responses in TNF receptor-associated factor 2 dominant negative mice. J Immunol 169:2828-2831

10. Lee SY, Reichlin A, Santana A, Sokol KA, Nussenzweig MC, Choi $\mathrm{Y}$ (1997) TRAF2 is essential for JNK but not NF-KB activation and regulates lymphocyte proliferation and survival. Immunity 7:703713

11. Villanueva JE, Malle EK, Gardam S et al (2015) TRAF2 regulates peripheral CD8(+) T cell and NKT cell homeostasis by modulating sensitivity to IL-15. Eur J Immunol 45:1820-1831

12. Walters S, Webster KE, Sutherland A et al (2009) Increased CD4+ Foxp3+ T cells in BAFF-transgenic mice suppress $\mathrm{T}$ cell effector responses. J Immunol 182:793-801 
13. Marino E, Villanueva J, Walters S, Liuwantara D, Mackay F, Grey ST (2009) CD4(+)CD25(+) T cells control autoimmunity in the absence of B cells. Diabetes 58:1568-1577

14. Malle EK, Zammit NW, Walters SN et al (2015) Nuclear factor $\kappa B-$ inducing kinase activation as a mechanism of pancreatic $\beta$ cell failure in obesity. J Exp Med 212:1239-1254

15. La Gruta NL, Turner SJ, Doherty PC (2004) Hierarchies in cytokine expression profiles for acute and resolving influenza virus-specific $\mathrm{CD} 8^{+} \mathrm{T}$ cell responses: correlation of cytokine profile and TCR avidity. J Immunol 172:5553-5560

16. Gardam S, Sierro F, Basten A, Mackay F, Brink R (2008) TRAF2 and TRAF3 signal adapters act cooperatively to control the maturation and survival signals delivered to B cells by the BAFF receptor. Immunity 28:391-401

17. Hacker H, Tseng PH, Karin M (2011) Expanding TRAF function: TRAF3 as a tri-faced immune regulator. Nat Rev Immunol 11:457468

18. Firan M, Dhillon S, Estess P, Siegelman MH (2006) Suppressor activity and potency among regulatory $\mathrm{T}$ cells is discriminated by functionally active CD44. Blood 107:619-627

19. Sun JC, Bevan MJ (2003) Defective CD8 T cell memory following acute infection without CD4 T cell help. Science 300:339-342

20. Gramaglia I, Weinberg AD, Lemon M, Croft M (1998) Ox-40 ligand: a potent costimulatory molecule for sustaining primary $\mathrm{CD} 4$ T cell responses. J Immunol 161:6510-6517

21. Pollok KE, Kim YJ, Zhou Z et al (1993) Inducible T cell antigen 41BB. Analysis of expression and function. J Immunol 150:771-781

22. Yang DD, Conze D, Whitmarsh AJ et al (1998) Differentiation of $\mathrm{CD}^{+} \mathrm{T}$ cells to Th1 cells requires MAP kinase JNK2. Immunity 9: $575-585$

23. Kelly BL, Locksley RM (2000) Coordinate regulation of the IL-4, IL-13, and IL-5 cytokine cluster in Th2 clones revealed by allelic expression patterns. J Immunol 165:2982-2986

24. Mottram PL, Han WR, Purcell LJ, McKenzie IF, Hancock WW (1995) Increased expression of IL-4 and IL-10 and decreased expression of IL-2 and interferon-gamma in long-surviving mouse heart allografts after brief CD4-monoclonal antibody therapy. Transplantation 59:559-565

25. Takeuchi T, Lowry RP, Konieczny B (1992) Heart allografts in murine systems. The differential activation of Th2-like effector cells in peripheral tolerance. Transplantation 53:1281-1294

26. Davidson C, Verma ND, Robinson CM et al (2007) IL-13 prolongs allograft survival: association with inhibition of macrophage cytokine activation. Transpl Immunol 17:178-186

27. Hildebrandt GC, Choi SW, Mueller G, Olkiewicz KM, Moore BB, Cooke KR (2008) The absence of donor-derived IL-13 exacerbates the severity of acute graft-versus-host disease following allogeneic bone marrow transplantation. Pediatr Blood Cancer 50:911-914

28. Sun $X$, Yamada $H$, Shibata $K$ et al (2010) CD30 ligand/CD30 plays a critical role in Th17 differentiation in mice. J Immunol 185:22222230

29. Antonysamy MA, Fanslow WC, Fu F et al (1999) Evidence for a role of IL-17 in organ allograft rejection: IL-17 promotes the functional differentiation of dendritic cell progenitors. J Immunol 162: $577-584$

30. Tang JL, Subbotin VM, Antonysamy MA, Troutt AB, Rao AS, Thomson AW (2001) Interleukin-17 antagonism inhibits acute but not chronic vascular rejection. Transplantation 72:348-350

31. Yeh WC, Shahinian A, Speiser D et al (1997) Early lethality, functional NF- $\mathrm{KB}$ activation, and increased sensitivity to TNF-induced cell death in TRAF2-deficient mice. Immunity 7:715-725

32. Kumar P, Ban HS, Kim SS et al (2008) T cell-specific siRNA delivery suppresses HIV-1 infection in humanized mice. Cell 134: 577-586

33. Arora M, Gowda S, Tuscano J (2016) A comprehensive review of lenalidomide in B cell non-Hodgkin lymphoma. Ther Adv Hematol 7:209-221

34. Yarza R, Vela S, Solas M, Ramirez MJ (2015) c-Jun N-terminal Kinase (JNK) signaling as a therapeutic target for Alzheimer's disease. Front Pharmacol 6:321

35. Yin MJ, Yamamoto Y, Gaynor RB (1998) The anti-inflammatory agents aspirin and salicylate inhibit the activity of IKB kinase- $\beta$. Nature 396:77-80 